\title{
О. О. Аюбіч
}

доктор економічних наук, професор, заслужений економіст України, віце-президент ДННУ “Академія фінансового управління", Київ, Україна, alyubich@ukr.net ORCID ID: https://orcid.org/0000-0002-9339-4242

\section{Г. П. Бортніков}

кандидат економічних наук, незалежний експерт, аналітик з ризиків Agents for Impact GmbH \& Co.KG (Франкфурт, Німеччина), Київ, Україна, gbgood@ukr.net ORCID ID: https://orcid.org/0000-0001-8388-6721

\section{Н. П. Шумьга}

доктор економічних наук, професор, завідувач кафедри банківської справи Київського національного торговельно-економічного університету, Київ, Україна, 2bank2@ukr.net ORCID ID: https://orcid.org/0000-0002-2010-5884

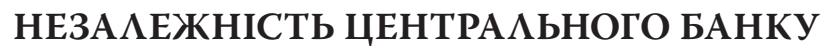 ЯК ОРГАНУ МОНЕТАРНОÏ ПОАІТИКИ ${ }^{1}$}

\begin{abstract}
Анотація. У статті аргументовано, що в умовах системних криз на центрацьні банки як органи монетарної політики покцадається відповіАальність за забезпечення цінової, фінансової та макроекономічної стабільності, однак такий піАхіА може розмивати межу між монетарною й фіскацьною політикою, а також загрожувати втратою їх незалежності піА політичним тиском. Ао того ж необхіАно визначитися 3 прийнятним рівнем автономії центрацьного банку, зАатного на рішення, котрі нейтралізують позитивний ефект фіскацьних заходів, особливо спрямованих на стиму-

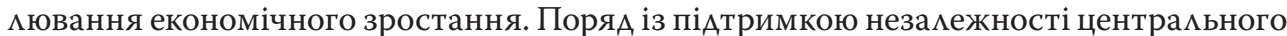
банку сліА критично переосмислити швиАкість, Аоцільність і масштабність вжитих ним антикризових заходів. Основними детермінантами піАтримки незалежності є: підзвітність, змістовність розкриття інформації та обгрунтованість оцінок Аіяльності за чіткими критеріями, до яких, зокрема, можна віАнести віАповіАність корпоративного управління встановленим стандартам і наявність механізму колегіацьного прийняття рішень щодо монетарної політики. АовеАено Аоцільність щорічного моніторингу модифікованого індексу незалежності Національного банку України через порівняння його з віАповіАним показником у країнах із подібним рівнем розвитку економіки.
\end{abstract}

Кмючові слова: центральний банк, монетарна політика, фіскальна політика, фінансова безпека, мобіювання, корпоративне управління.

Рис. 2. Табц. 4. Міт. 30.

\section{Oleksandr Lyubich}

Dr. Sc. (Economics), Professor, Honored Economist of Ukraine,

SESE "The Academy of Financial Management", Kyiv, Ukraine, alyubich@ukr.net

ORCID ID: https://orcid.org/0000-0002-9339-4242

\section{Gennadiy Bortnikov}

Ph. D. (Economics), Agents for Impact GmbH \& Co.KG, Kyiv, Ukraine, gbgood@ukr.net

ORCID ID: https://orcid.org/0000-0001-8388-6721

\section{Nataliia Shulga}

Dr. Sc. (Economics), Professor, Kyiv National University of Trade and Economics,

Kyiv, Ukraine, 2bank2@ukr.net

ORCID ID: https://orcid.org/0000-0002-2010-5884

${ }^{1}$ Статтю підготовлено в рамках проекту, що виконується за грантової підтримки Націонамьного фонду досліджень України (реєстраційний номер: 2020.01/0546).

(с) Аюбіч О. О., Бортніков Г. П., Шульга Н. П., 2020 


\title{
INDEPENDENCE OF THE CENTRAL BANK AS A MONETARY POLICY AUTHORITY
}

\begin{abstract}
The central banks as bodies of monetary policy have a special mission to promote financial stability. Fulfilling this mission can blur the line between monetary and fiscal policy and threaten to independence of monetary authority under the political pressure. On the other hand, the central bank cannot be a completely autonomous structure that makes irresponsible decisions, which neutralize the positive effect of fiscal measures, especially in stimulating the economic growth. There is a risk of wrong or improper monetary policy decisions by a collegium that lacks a balance of power between representatives of stakeholders. The central bank management should take into account government recommendations, but should not follow its instructions as directives. This dilemma is particular complicated in emerging economies. Monetary policy should be highly discretionary with dual goals: financial stability as a prior goal for a central bank followed by positively impact on the economic growth, which is measured by a set of indicators, including the rate of GDP growth and the reduction of unemployment. The independence of the central bank needs a critical rethinking in the context of large-scale anti-crisis extraordinary measures. An organic component of independence is central bank accountability, the content of information disclosure and validity of evaluations of its activities according to clear criteria. Moreover, it is necessary to determine the optimal level of central bank autonomy, which should not be equated with the usurpation of monetary power by the executives. The central bank's independence index can be considered as an indicator of security for monetary policy. It is expedient to carry out annual monitoring of the modified central bank independence index for a sample of peer group of countries with similar economic development to identify lag or lead for the National Bank of Ukraine in terms of the degree of independence.
\end{abstract}

Keywords: central bank, monetary policy, fiscal policy, financial security, lobbying, corporate governance.

JEL classification: E42, E52, E58.

\section{А. А.}

доктор экономических наук, профессор, заслуженный экономист Украины, вице-президент ГУНУ “Академия финансового управления", Киев, Украина

\section{Г. П. Бортников}

кандидат экономических наук, независимый эксперт, аналитик по рискам Agents for Impact GmbH \& Co.KG (Франкфурт, Германия), Киев, Украина

\section{Н. П. Шумьга}

доктор экономических наук, профессор, заведующая кафедрой банковского дела

Киевского национального торгово-экономического университета, Киев, Украина

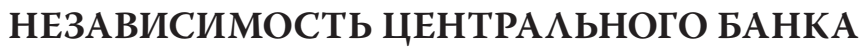 КАК ОРГАНА МОНЕТАРНОЙ ПОАИТИКИ}

Аннотация. В статье аргументировано, что в условиях системных кризисов на центрацьные банки как органы монетарной политики возмагается ответственность за обеспечение ценовой, финансовой и макроэкономической стабильности, но такой поАход может размывать границу межАу монетарной и фискаАьной помитикой, а также угрожать потерей их независимости поА политическим Аавлением. К тому же необходимо определиться с приемлемым уровнем автономии центрацьного банка, способного к решениям, которые нейтрацизуют положительный эффект фискальных мер, особенно направленных на стимукирование экономического роста. НаряАу с поААержкой независимости центрацьного банка слеАует 
критически переосмыслить скорость, целесообразность и масштабность принятых им антикризисных мер. Основными детерминантами подАержки независимости явАяются: подотчетность, содержатеАьность раскрытия информации и обоснованность оценок Аеятельности по четким критериям, к которым, в частности, можно отнести соответствие корпоративного управления установленным станАартам и нацичие механизма колцегиацьного принятия решений по монетарной политике. Аоказана целесообразность ежегодного мониторинга модифицированного индекса независимости Национацьного банка Украины посредством сравнения его с соответствующим показателем в странах с подобным уровнем развития экономики.

Кмючевые слова: центральный банк, монетарная политика, фискальная политика, финансовая безопасность, моббирование, корпоративное управление.

Концепція незалежності центрального банку (далі - ЦБ) історично обстоювацась як необхідна перешкода політичному тиску з боку правлячих політиків (уряду) на орган монетарної поцітики. Цей тиск, особливо у періоА виборчих перегонів, полягає у примусі до заходів, спрямованих на наАмірну ін'єкцію грошової бази, що призведе Ао зростання інфмяції. Механізм забезпечення незалежності ЦБ в Україні відповіАно до найкращої міжнародної практики був сформований у 2015 р. у зв'язку з прийняттям нової реАакції Закону України «Про Націонахьний банк України». ОАнак, аби зазначений механізм працював, потрібно дотримуватися встановлених норм.

Як піАкреслив преАставник МВФ, політичний істеблішмент захищатиме незалежність ЦБ, коли його Аії піААають сумніву, тож її поважатимуть і за буквою, і за Аухом закону [1]. В інтересах націонацьної безпеки центробанк повинен бути зАатний проводити монетарну політику Аискреційно, тобто на власний розсуА, керуючись не вказівками уряду, а міркуваннями щодо цінової, фінансової й макроекономічної стабільності. Проте в сучасних умовах боротьби із системною кризою практично в усіх країнах уряд і ЦБ мають обєАнувати свої зусимця та при цьому поступатися своєю незамежністю, погоджуючись на компроміси. Кількісне пом'якшення призвело Ао розмивання межі між монетарною й фіскацьною політикою.

У численних зарубіжних і вітчизняних наукових публікаціях переважає Аумка про необхідність збереження незалежності ЦБ. Напередодні кризи, спричиненої пандемією, Аослідження українських учених зосереАжувалися на визначенні параметрів та оцінці ступеня незалежності центробанку на основі віАповіАного індексу [2-4]. Гцобальна системна криза активізувала пошуки нових віАповіАей на нібито вже закриті питання. Більшість сучасних Аосліджень приводять Ао висновку про необхіАність або Аоречність розширення мандату ЦБ із взяттям віАповіАацьності за макроекономічну стабільність та виходу за межі монетарної стабі ьності [5-9]. Ао того ж чимало публікацій присвячено збереженню незалежності в умовах тіснішої, ніж коли-небудь, взаємодії ЦБ з урядом у реалізації антикризових заходів, націлених на подолання насліАків пандемії коронавірусу [10-12]. Поняття незалежності ЦБ набуває нового змісту, коли необхіАно врятувати економіку віА стагнації, а фінансовий сектор - віА системної кризи. 
Ці та інші проблеми стаци преАметом запекцої наукової полеміки, оАнак не Аістали оАнозначного розв'язання, що зумовило потребу у виконанні цього АосліАження. Його мета полягає в розробленні оновленого піАходу Ао розуміння незалежності ЦБ у контексті боротьби з насліАками пандемії та наступного віАновлення економіки. Цей піАхіА передбачає гармонійне поєАнання трьох цілей монетарної політики ЦБ - забезпечення фінансової, цінової та макроекономічної стабі ььності. Особливо актуацьно це за системної кризи, коли центробанк повинен шукати компроміси в Аотриманні “ієрархії цілей”. 3 одного боку, Аосягнення фінансової стабільності органічно доповнює стабільність цін, оскільки фінансова система, що безперебійно функціонує, забезпечує ефективний розподік заощаджень та інвестицій, сприяючи економічному зростанню та зайнятості. 3 Аругого боку, стабільне становище піАприємств і Аомогосподарств $€$ запорукою нормацьної Аія ььності фінансових установ та фінансової стійкості.

Заслуговує на увагу піАхіА американського економіста Аж. КАіфта, котрий слушно зазначив: коли центробанк постає переА Аилемою - фінансова стабільність чи цінова, у виборі цілей сліА ураховувати ефект Аля забезпечення сталого економічного зростання й раціонацьної зайнятості [13].

На наш погляА, цінова стабільність не може бути самоціл ю, оскільки суспільним благом є не низька інфцяція, а національний Аобробут. Тож постає природне питання: яка користь народу України зі стабілізації цін, коли зростає безробіття й закриваються піАприємства? У вітчизняних реаліях це питання поки залишається віАкритим.

Незалежність ЦБ означає, що він має бути захищений віА кон'юнктурного впливу, політичного тиску, особливо коли правцяча партія примушує Ао наАмірного нарощування грошової маси, проводить експансивну монетарну політику заАля зменшення безробіття, яка Аасть змогу Аосягти цього Аише на короткий час, а в сереАньостроковій перспективі призвеАе, зокрема, Ао зниження конкурентоспроможності економіки та підвищення інфляції.

Пропонуємо розрізняти формальну (де-юре) і фактичну незалежність ЦБ. Формальна незалежність закріплена у віАповідних законодавчих актах та підтверАжується в програмних документах і виступах державних Аіячів, а фактична проявцяється у конкретних подіях, пов'язаних із прийняттям рішень $з$ монетарної помітики й кадрових призначень.

У вузькому розумінні піА політичною незалежністю ЦБ мають на увазі його роль як органу монетарної помітики. Проте варто враховувати, що Націона ьний банк України (далi - НБУ) також $є$ органом пруденційного нагляду за фінансовим сектором і взагалі віАповіАає за фінансову стабільність. У $Є С$ центробанки функціонують у євросистемі на чолі з Європейським центральним банком (далi - ЄЦБ). Перспектива інтеграції нашої країни в ЄС передбачає конвергенцію нормативної бази. ЗгіАно зі ст. 130 Аоговору про Європейський Союз, незалежність національних центробанків ЄС охоплює функціональну, інституційну, калрову та фінансову незалежність. Функціона^ьна переАбачає чітко визначену мету й самостійність ЦБ у виборі захоАів 
та інструментів Аля її реалізації, інституційна вказує на те, що його рішення вільні віА впливу інших установ чи уряду. Кадрова незалежність гарантує захист посадових осіб ЦБ віА зовнішнього тиску, викцючає конфлікт інтересів і точно визначає умови обрання й звільнення очільника та інших членів органу виконавчої влади в центробанку, фінансова - можиивість самостійного отримання фінансових ресурсів Аця виконання свого мандату.

Економісти А. КунайАі та А. Аарванто критично розглянули постулат про обернену кореляцію між незалежністю ЦБ та інфляцією, яка стала консенсусом, котрому Аовіря и в усьому світі [14]. Вони визнали, що немає оАнозначного пояснення, чому та як незалежність ЦБ дала можливість стримати інфмяцію. АосліАники проаналізуваци інформацію по 20 країнах Азії 3 інституційною різноманітністю за Аопомогою Аинамічного піАходу Ао вибірки даних. Результати дослідження свідчать: вказана кореляція визначається рівнем розвитку фінансового сектору, а також інституційною якістю кожної країни.

Американський експерт М. Собел звертає увагу на те, що ЦБ не $є$ абсомютно незалежними [15]. По-перше, вони звітують переА парламентом; поАруге, координують свою політику з міністерствами фінансів. Річ не в тім, чи повинні такі банки мати необмежену свободу, або навпаки, бути піАпорядкованими урядам, а в тім, чи є кращим Аля суспільства, коли центробанк самостійно обирає інструменти монетарної політики, не консультуючись із виконавчою владою. М. Собел підтримує незалежність ФеАера ьної резервної системи (далi- ФРС) США у використанні інструментів, але при цьому визнає, що їі зАатність визначати монетарну політику може істотно погіршитися через пандемію. Фіскальне домінування, фінансові репресії й безвіАповіАальність політиків можуть загрожувати репутації ФРС. Аби поАолати цей ризик, США повинні піАтримати ФРС у плані піАзвітності та вповноважити їі на служіння процвітанню економіки країни.

Проблема незалежності ЦБ загострюється внаслідок конфмікту цілей монетарної й фіскальної політики. Голова Інституту фінансової стабільності при Банку міжнародних розрахунків Ф. Рестой закмикає досліАників і регуАяторів уважно ставитися Ао вибору конкретних інструментів Аһя Аосягнення цілей: застосування інструментів монетарної політики може послабити ефект інструментів макроекономічної політики [16]. СправАі, перегляА кАючової ставки або запуск програми викупу цінних паперів може вплинути не $и$ не на цінову, а й на фінансову та макроекономічну стабільність.

Експерт А. Масціандаро розгляАає форму фіскальної монетизації, котра призводить до зменшення балансу ЦБ без постійного збільшення грошової бази [9]. На його Аумку, якщо віАповіАальний уряА скмадається з політиків, зацікавцених у кар'єрі, а громаАянський рух неоАноріАний, то коорАинація політик (фіскацьної й монетарної) призведе до конфміктів між політиками та керівниками центробанку.

В. Ю. Аудченко, аналізуючи зарубіжний досвіА, доводить: забезпечення незалежності ЦБ визначається кількома факторами, а саме: взаємодією мо- 
нетарної й державної економічної політики, структурою банківської системи та видом монетарної політики. Автор піАкреслює, що незалежність ЦБ передбачає самостійність у окресленні цілей та інструментів монетарної поАітики з урахуванням Аовгострокових цілей економічного розвитку. На переконання АосліАниці, крім цінової стабільності до цілей Аіяльності ЦБ сліА віАнести зайнятість, фінансову стабільність, сприяння економічному розвитку, стабільність платіжної системи [5].

Центральні банки зАатні мобілізувати фінансові ресурси швидше за будь-який інший орган влаАи. АосліАження свідчать, що баланс ЦБ істотно зростає паралельно зі збільшенням державного боргу, внасліАок чого посимюється зв'язок між фіскацьною й монетарною політикою. 3 метою уникнення цього в майбутньому необхіАно захистити незалежність центробанку та Аовіру до нього.

3 метою оцінювання рівня незалежності ЦБ в зарубіжній практиці широко використовується методика обчислення віАповіАного індексу. Найпопумярнішим $є$ індекс незалежності центробанку (Central Bank Independence CBI ), базову версію якого в 1990-х роках разом із колегами розробив ізраїльський економіст А. Цукерман [17]. Цей індекс грунтується на розрахунку чотирьох компонентів із використанням 16 індикаторів. Основним компонентом $€$ посада Голови центрального банку (вага в індексі 0,2), котра характеризується тривахістю терміну повноважень, органом, якому Аелеговано призначення; поряАком звільнення; можАивістю обіймати ще оАну посаду. Органічною скцадовою індексу є незалежність політики (вага в індексі 0,15), що вкцючає віАповіАа ьність ЦБ за формулювання монетарної політики, правила розв'язання конфліктів між ним і урядом, а також його участь у скмаданні бюджету. Компонент “Цілі центрацьного банку” (вага 0,15) визначає монетарну стабільність як одну з основних цілей політики. Останній складник індексу “Обмеження щодо надання кредитів центральним банком Аержавному сектору” розглядається як еквівалент фінансової незалежності та має найбільшу частку - 0,5. На сьогодні в рамках піАтримки $і$ іквіАності фондового ринку ЦБ багатьох країн вдалися до масштабного інвестування в боргові фінансові інструменти урядів. Разом із тим націонацьними нормативними актами про ЦБ заборонено креАитування уряАу, в т. ч. приАбання суверенних цінних паперів на первинному ринку.

Методологія розрахунку індексу незалежності ЦБ, на наш погляА, потребує модифікації. По-перше, пропонуємо Аоповнити Аругий компонент статусом і порядком формування скмаду Комітету з монетарної політики. Анаціз передової практики європейських банків показує: такі колегіальні органи мають створюватися з балансом представництва трьох категорій: вищого керівництва центробанку, урядовців та зняти експертів. Це Аає можиивість запобігти узурпації влаАи в органі монетарної помітики. ПоАруге, в третьому компоненті індексу незалежності ЦБ потрібно розбити цілі на Аосягнення цінової, фінансової та макроекономічної стабільності (сталого приросту ВВП і граничного рівня безробіття), що розширює сферу 
віАповіАальності ЦБ й узгоджується з його місією. По-третє, варто перегАянути критерій четвертого компонента в частині викупу цінних паперів.

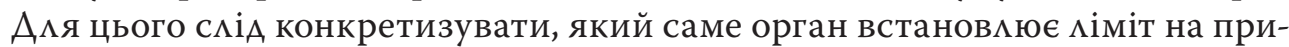
Абання портфеля Аержавних цінних паперів. Це оАнозначно не може бути внутрішньокорпоративним рішенням, аАже стосується інструментарію монетарної політики та має бути схвалене Комітетом з монетарної політики. По-четверте, при обчисленні індексу Аоречно Аоповнити його ще оАним критерієм оцінки незалежності ЦБ - піАзвітністю та розкриттям інформації.

На нашу Аумку, є певна загроза Аля національної фінансової безпеки, генерована абсолютизацією незалежності ЦБ: передання останньому всіх повноважень із розроблення й реалізації монетарної політики не забезпечить захисту суспільних інтересів, оскільки в такому разі Аіяльність ЦБ переходить піА контроль групи осіб, а не суспільства. Таку загрозу в демократичному суспі цьстві можна нейтралізувати за Аопомогою механізму піАзвітності центробанку інститутам, особистої відповіАальності його керівництва за Аосягнення цілей, наАання йому особливого статусу - органу, що приймає кмючові рішення з монетарної політики. Захист ЦБ віА втручання політичних інститутів (парламенту, президента) не означає його "недоторканності”, а навпаки, його підзвітність, тобто взяття керівниками віАповіАальності за ефективність монетарної політики.

Вважаємо за доцільне запропонувати щорічну оцінку НБУ виходячи 3 кмючових положень індексу незалежності ЦБ. На наш погляА, незалежність повинна гарантуватися механізмом піАзвітності, а належна практика піАзвітності ЦБ передбачає: 1) пубцічність, прозорість, регулярність і повноту звітів; 2) передбачуваність Аій (рішень) центробанку та Комітету з монетарної політики Аля учасників ринку; 3) наявність незалежного аудиту такої політики та правильне застосування інструментів; 4) звітування профімьному комітету парламенту. Прозорість вк ючає повноту звітів А я коментарів експертами, публічність - розкриття достатньої інформації А я всіх зацікавлених сторін, зокрема громадських кіл. ПіА передбачуваністю рішень із монетарної політики ми розуміємо віАповіАність і своєчасність вжиття заходів з огляду на масштаби стресів. Це не означає, що орган монетарної політики не може вжити надзвичайних або неординарних заходів, якщо Аоцільно. ОАнак такі рішення повинні бути спрямовані на посилення позитивних сигнаців ринку. Всі зацікавлені сторони, у т. ч. інвестори, банки, піАприемства, домогосподарства, мають отримувати правильні сигнали, а не Аіяти в умовах невизначеності. Це зміцнюватиме довіру в суспі ььстві до монетарної політики та органу, котрий її проводить.

Австрійський експерт М. Кюпфер перевіряє гіпотезу про піАвищену по-

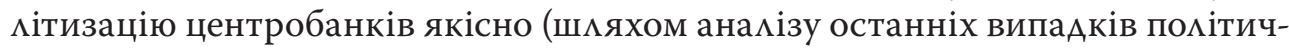
ного втручання) й кількісно (на піАставі розрахунку індексу автономії ЦБ (Grilli-Masciandaro-Tabellini index of central bank - GMT). Він пояснює посилення політичного втручання в монетарну політику кількома факторами: 
розширенням набору інструментів, активним популізмом і дедахі суперечмивішою політикою уряду [18].

Аоречно конкретизувати зазначене поняття. Суб'єктами політичного тиску можуть виступати партії, парламент, громадські організації, уряА, президент та його аАміністрація; формою - офіційні заяви преАставників цих суб'єктів зі звинуваченнями керівництва ЦБ у некомпетентності, недбайливості, безвідповідальності чи упередженості. Найчастіше згадані суб'єкти чинять політичний тиск на регулятора монетарної політики, вимагаючи вжити заходи, які суперечать реалізації цілей монетарної політики:

- зниження кмючової ставки;

- полегшення умов Аоступу банків до рефінансування;

- збільшення грошової маси (Арук наАмірної кількості грошей).

Усі інші звинувачення щодо причетності НБУ Ао масового закриття слабких банків або несвоєчасного реагування на їхню занадто ризикову Аіяльність стосуються сфери нагляАу (пруденційної політики). Формою політичного тиску ми вважаємо також ініціативи, спрямовані на внесення змін Ао законодавчої бази, котрі призводять до обмеження або скасування неза-

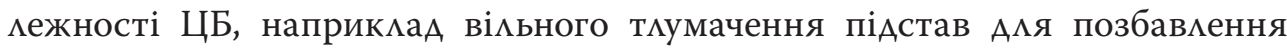
очільника ЦБ обов'язків чи підзвітності останнього. Аля України характерний опосереАкований вплив на центробанк у процесі формування скмаАу РаАи НБУ, що схвалює (за поданням Голови Нацбанку) призначення і звільнення заступників Голови.

Монетарна політика ЦБ повинна бути преАметом неупереАженого, критичного анаАізу, а його керівники - об'єктом конструктивної критики. БуАь-

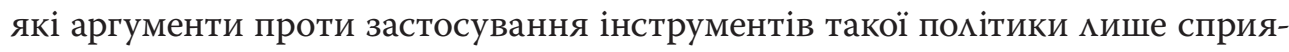
ють ухваленню ним обгрунтованіших рішень, піАвищують його віАповіАальність. На нашу Аумку, центробанк (і його очільник) має бути не тільки наАійно захищений віА загрози волюнтаризму з боку законодавчої чи іншої гілки вцаАи, а й зАатний протистояти необгрунтованим напаАам та ква $і ф і-$ ковано, переконмиво реагувати на критику або адекватно сприймати скушні зауваження.

C. Кахверхаус, експерт компанії “Tellimer Research”, констатує, що загрози незалежності ЦБ накопичуються роками, а в умовах пандемії актуалізуються. Окрім того, ринки, які розвиваються, зазвичай менше зАатні протистояти політичному тиску на центробанки, ніж розвинуті [19]. Аیя країн, котрі найбільше постражАали віА пандемії, це може означати негативний вплив на прип ив капіталу та націонацьну валюту.

Як АоАатковий критерій незалежності ЦБ пропонуємо розгляАати перебування призначених осіб на посаді його голови. Анаціз ротацій у керівництві центробанків ЗахіАної й Центрацьної Європи за 2010-2020 рр. показав, що найчастіше вони працюють повний строк, передбачений законом

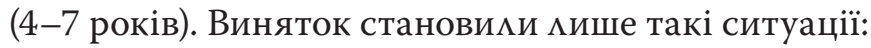

- загибель у авіакатастрофі 2010 р. очільника Націонацьного банку Помьщі; 
- звільнення за власним бажанням голови Націонацьного банку Сербії (НБС) у 2012 р., уже через Ава роки після призначення, у зв'язку з його незгодою зі змінами до закону про центробанк, котрі, на його Аумку, суттєво обмежують незалежність ЦБ та можуть призвести Ао економічної й фінансової нестабільності у країні;

- звільнення за вцасним бажанням очільника Національного банку МолАови у 2016 р. у зв’язку зі звинуваченнями в корупції та його наступника у 2018 р. 3 “особистих причин";

- звільнення голови Центрального банку Турецької Республіки у 2019 р. після його незгоАи на зниження кцючової ставки та його наступника в 2020 р., через 16 місяців після призначення (неофіційна причина - рекордна Аевальвація національної валюти).

Водночас в Україні за цей період (2014-2020рр.) змінилося шість очільників НБУ - всі вони скмали свої повноваження достроково (сереАній термін обіймання посаАи Голови НБУ становив 546 Анів, найкоротший 105 Анів). Приблизно 3 такою самою частотою віАбувалася ротація Уряду.

Варто враховувати, що плинність кадрів на такій посаді може бути низькою, якщо очільник бажає виконувати волю політиків, у інших випаАках він може бути усунений через незадовікьні результати дія ьності [20]. У зв’язку 3 цим цікавий висновок зробила К. Біндер: у країнах із потужнішим суперництвом на виборах чи кращим балансом сил (між партіями) випаАки поАітичного тиску трапцяються не так часто [21].

На Аіяльність ЦБ впливає не тільки його політична, а й фінансова незалежність. Нещодавнім прикладом спроб обмеження незалежності центробанку є вкАючення в заплановані на 2021 р. Аоходи Аержавного бюАжету наАходжень у розмірі 45 мирА грн віА НБУ без погодження із самим банком та затверАження незалежним аудитом результатів фінансового року. Тож негативна реакція очільника Нацбанку була цілком могічною [22].

АосліАники А. Керн і Аж. СеААон констатують: у Індії, Індонезії, Україні та інших країнах законодавці посилюють політичну владу наА органами монетарної політики. Ці приклади віАображають нову реальність у окресленій сфері - політичний віАступ віА незалежності ЦБ [7]. ПараАоксацьно, що на підставі аналізу преАставницької вибірки країн названі вчені визнали зовнішній фактор основним аргументом запроваАження незалежності ЦБ, а саме вимогу з боку кредиторів суверена, таких як держави, міжнародні організації, вітчизняні й міжнародні приватні банки, Аця зменшення ризиків, пов'язаних із суверенними боргами. Ця теза знаходить підтверАження й в Україні, аАже саме міжнародні креАитори висловими занепокоєння політичним тиском на керівника НБУ $[1 ; 23 ; 24]$.

Водночас постає питання реальності впливу головного інструменту монетарної політики - кАючової ставки - на темп інфмяції, якщо обсяги рефінансування банків незначні порівняно 3 їхньою ресурсною базою. Найістотніше зниження облікової ставки відбулося в січні й квітні 2020 р., після виборів Президента України в березні 2019 р. 


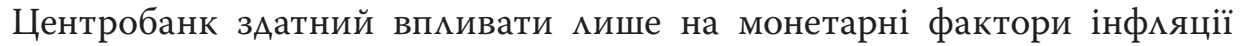
шляхом регумювання маси грошей у обігу й частково - за рахунок впливу на швиАкість їх обігу. Немонетарні фактори інфцяції (піАвищення попиту на товари та послуги, збільшення витрат виробництва, сезонні чинники, Аержавне регулювання тарифів, встановлення монопольних цін тощо) перебувають за межами його контролю.

3бір Ааних і визначення рівня інфцяції не $є$ прерогативою ЦБ. Інформацію про споживчі ціни й тарифи щомісяця акумулюють фахівці територіальних органів Аержавної служби статистики України Аля товарів і послуг, які входять Ао споживчого набору. ОАнак, оскільки цінова стабільність (цільовий рівень інфляції) належить Ао головних завАань монетарної політики, Аоцільно провоАити регулярний аудит Аостовірності розрахунків темпу інфцяції (контролю якості в обробці статистики). Зокрема, в умовах скорочення Аоходів Аомогосподарств статистика може показувати зниження цін, коли споживачі оАного товару переходять із магазинів з високими цінами на магазини з помірнішими цінами або замінюють товари на менш якісні, але дешевші.

Якщо рівень інфляції вимірюється Аостовірно, то наступним кроком $є$ критичний аналіз співвіАношення її темпів і кцючової ставки. Вважається, що між темпами зміни кцючової ставки ЦБ та інфцяції існує Аодатна кореляція.

ПіА час пандемії практично в усіх країнах органи монетарної помітики знизили кАючову ставку до історичного мінімуму, проте в найбільш розвинутих Аержавах вона ще до пандемії наближалася до нульового рівня, тому можиивість зменшувати цю ставку мали фактично тільки окремі країни. Єврозона не переглядала кмючову ставку в період пандемії (збережена на нульовому рівні), так само як Швеція та Болгарія. ВіА’ємні кцючові ставки залишаються у Швейцарії й Аанії. Вибірка країн СхіАної Європи відображає Аоволі хаотичний розкиА у значеннях інфцяції та кмючової ставки (табл. 1).

Та б и ц я 1. Кмючова ставка органів монетарної помітики та її співвіАношення з інфмяцією в окремих країнах Східної Європи у 2020 р.

\begin{tabular}{|l|c|c|c|c|}
\hline \multicolumn{1}{|c|}{ Країна } & $\begin{array}{c}\text { Ключова } \\
\text { ставка }\end{array}$ & $\begin{array}{c}\text { 3міна, } \\
\text { в. п. }\end{array}$ & $\begin{array}{c}\text { Інфляція станом } \\
\text { на вересень 2020 р. }\end{array}$ & Ключова ставка / інфляція \\
\hline Чехія & 0,25 & $-0,75$ & 3,20 & 7,81 \\
Угорщина & 0,60 & $-0,15$ & 3,40 & 17,65 \\
Польща & 0,10 & $-0,40$ & 3,00 & 3,33 \\
Росія & 4,25 & $-0,25$ & 4,00 & 106,25 \\
Білорусь & 7,75 & $-0,25$ & 6,10 & 127,05 \\
Болгарія & 0 & $-0,01$ & 0,90 & 0 \\
Молдова & 2,65 & $-0,10$ & 2,30 & 115,22 \\
Румунія & 1,50 & $-0,25$ & 2,50 & 60,00 \\
Сербія & 1,25 & $-0,25$ & 1,80 & 69,44 \\
Україна & $\mathbf{6 , 0 0}$ & $-\mathbf{2 , 0 0}$ & $\mathbf{2 , 6 0}$ & $\mathbf{2 3 0 , 7 7}$ \\
\hline
\end{tabular}

Складено за: Worldwide Central Bank Rates. URL: http://www.cbrates.com; Inflation Rate / Trading Economics. URL: https://tradingeconomics.com/country-list/inflation-rate. 
Та бл и ц я 2. Група країн, Ае кмючова ставка у 2020 р. істотно перевищує темпи інфмяції

\begin{tabular}{|l|c|c|c|c|}
\hline \multicolumn{1}{|c|}{ Країна } & $\begin{array}{c}\text { Ключова } \\
\text { ставка }\end{array}$ & $\begin{array}{c}\text { Зміна, } \\
\text { в. п. }\end{array}$ & $\begin{array}{c}\text { Інфляція станом } \\
\text { на вересень 2020 р. }\end{array}$ & Ключова ставка / інфляція \\
\hline Йорданія & 2,50 & $-1,00$ & 0,10 & 2500,00 \\
Тринідаді і Тобаго & 3,50 & $-1,50$ & 0,60 & 583,33 \\
Південна Корея & 0,50 & $-0,25$ & 0,10 & 500,00 \\
Монголія & 8,00 & $-1,00$ & 1,70 & 470,59 \\
Вірменія & 4,25 & $-0,25$ & 1,30 & 326,92 \\
Мозамбік & 10,25 & $-1,00$ & 3,20 & 320,31 \\
Індонезія & 4,00 & $-0,25$ & 1,44 & 277,78 \\
Єгипет & 8,75 & $-0,50$ & 3,70 & 236,49 \\
Україна & $\mathbf{6 , 0 0}$ & $-\mathbf{2 , 0 0}$ & $\mathbf{2 , 6 0}$ & $\mathbf{2 3 0 , 7 7}$ \\
Китай & 3,85 & $-0,20$ & 1,70 & 226,47 \\
Азербайджан & 6,50 & $-0,25$ & 2,90 & 224,14 \\
Грузія & 8,00 & $-0,25$ & 3,80 & 20,53 \\
Ботсвана & 3,75 & $-0,50$ & 1,80 & 208,33 \\
\hline
\end{tabular}

Складено за Worldwide Central Bank Rates. URL: http://www.cbrates.com; Inflation Rate / Trading Economics. URL: https://tradingeconomics.com/country-list/inflation-rate.

Співвідношення кАючової ставки та інфцяції істотно різниться по країнах: у одній групі (Ао якої входить Україна) ця ставка значно перевищує темпи інфмяції (табл. 2), у Аругій - навпаки, інфмяція набагато більша віА кмючової ставки, у третій - показники наближені один до одного (рис. 1, 2).

Питання незалежності центробанків набуло нового звучання у зв'язку з масштабними операціями ЄЦБ та ЦБ Західної Європи з придбання суверенних облігацій. Показовим $\epsilon$ рішення Федерального конституційного суду Німеччини віА 05.05.2020, яке стосується монетарної політики ЄЦБ [25]. Останній не зміг обгрунтувати програму придбання активів, започатковану в 2015 р. Закупівлі перевищили 2 трлн євро облігацій державного боргу. Ця судова справа важлива не мише Аля Європи, оскільки ЄЦБ є Аругим за значимістю центробанком у світі, а глобальна фінансова стабільність залежить віА стабільності єврозони. СуА віАходить віА традиції довіряти монетарну політику незалежному ЦБ, котрий повинен забезпечувати стабі $\mathrm{b}$ ність цін. Він пригрозив заборонити ЦБ Німеччини брати участь у схемі викупу облігацій ЄЦБ, яка $€$ неприпустимою згіАно з Конституцією країни. Це рішення викликало незадоволення з боку Європейського суду, який вважає такі питання сферою своєї компетенції. На Аумку заступника керуючого ЄЦБ, політика цього банкупіАпорядковується вик ючно Суду Європейського Союзу і піАзвітна Європейському парламенту, а Бундесбанк співпрацює 3 Федеральним урядом Німеччини та Бундестагом [26].

Експерти висловлюють занепокоєння, оскільки рішення Федерального конституційного суду Німеччини стосується не тільки віАносин Німеччини з ЄЦБ та Судом $Є С$, а й конституційних засаА монетарної політики [27]. 


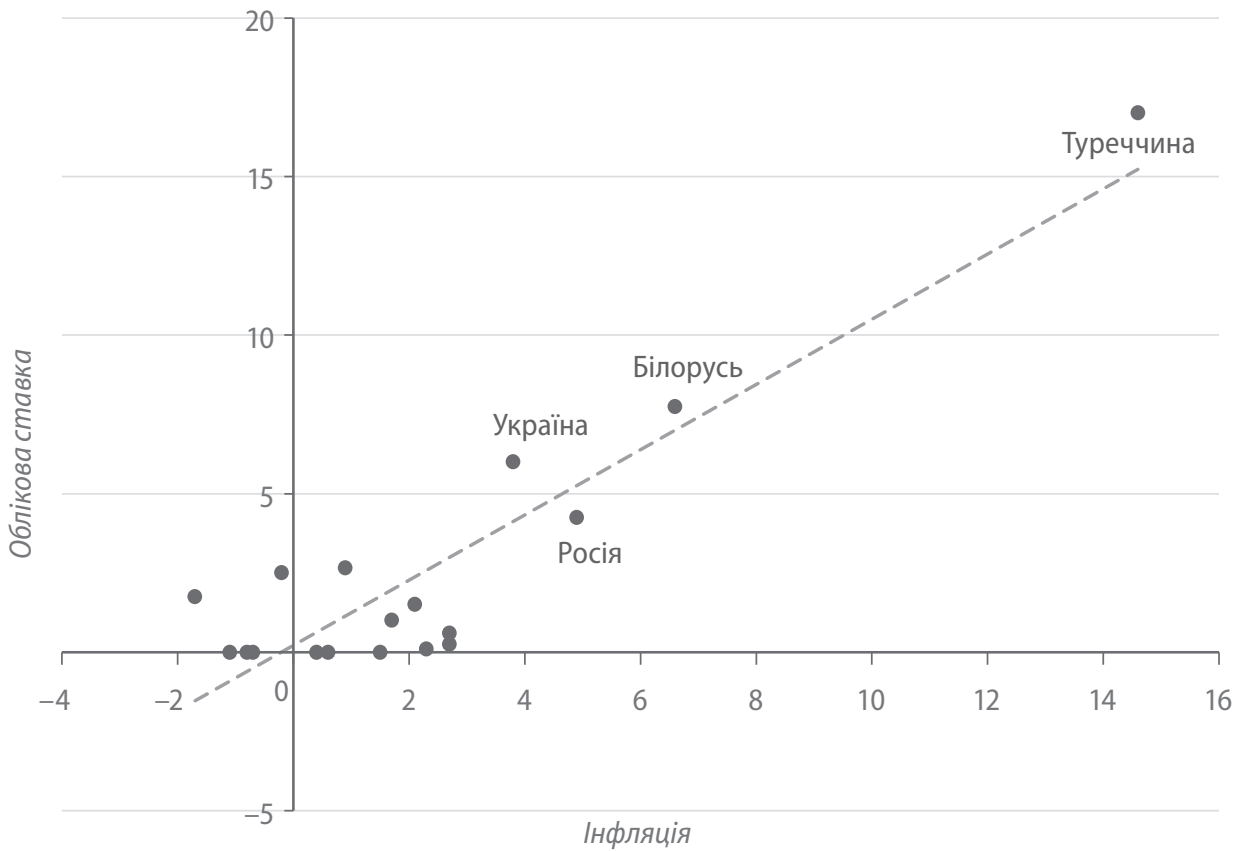

Р и с. 1. Розподім країн за рівнем кмючової ставки та інфмяції у 2020 р., \%

Складено за: Worldwide Central Bank Rates. URL: http://www.cbrates.com; Inflation Rate / Trading Economics. URL: https://radingeconomics.com/country-list/inflation-rate.

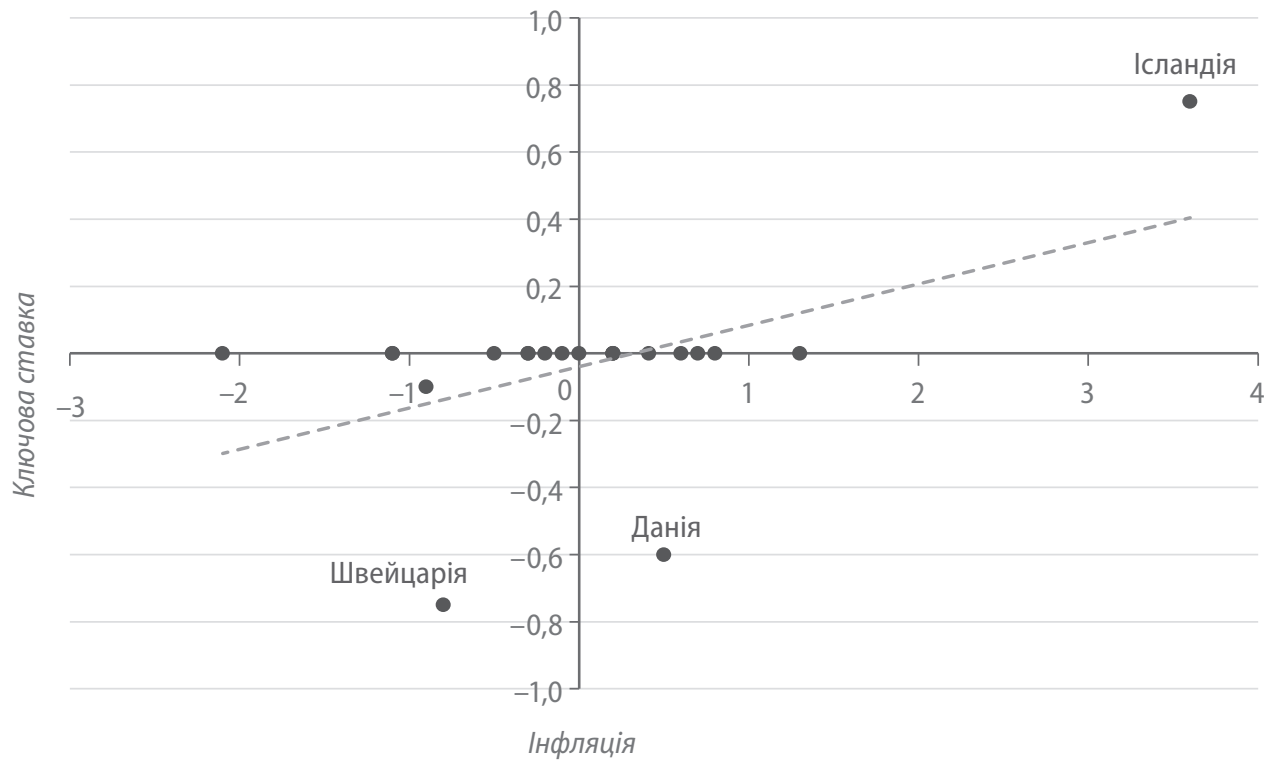

Р и с. 2. Розподіл країн G-20 за рівнем кмючової ставки та інфмяції (без урахування Аргентини й Туреччини) у 2020 р., \%

Складено за: Worldwide Central Bank Rates. URL: http://www.cbrates.com; Inflation Rate / Trading Economics. URL: https://tradingeconomics.com/country-list/inflation-rate. 
ВіАповіАно Ао поглядів фахівців, потрібна незалежність центробанку, аби гарантувати, що наА монетарною політикою не Аомінуватиме ситуативна економічна політика. Вимоги суду піАривають як виключну прихильність ЦБ стабільності цін, так і його незалежність, що має шкіАливі наслідки не мише Аля ЄЦБ, а й Аля Бундесбанку та стабільності євро.

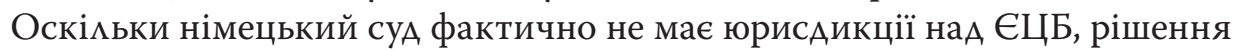
було винесено проти уряАу, котрий, як було встановлено, не виконав свого обов'язку захищати позивачів у суді віА надмірної політики ЄЦБ. Закмикаючи ЄЦБ обгрунтувати свою політику, німецький суА ставить піА сумнів Аоцільність незалежності центробанку - ЄЦБ переступає межу між монетарною та економічною політикою. СуА фактично визнає епохальну зміну в політиці ЦБ: віАбувається не просто перехіА віА монетарної Ао економічної політики, а віА моделі центробанку, чиїм завданням $є$ стримування інфляції, до ЦБ, чия Аіяльність полягає у запобіганні дефляції. Тобто ЦБ з вузькою політичною метою замінює установа, котра вживає заходи на піАтримку всіеї фінансової системи.

Про рівень незалежності ЦБ може свідчити також його частка у загальній масі державних цінних паперів в обігу. Як показує табл. 3, незважаючи на системну кризу, викликану пандемією, НБУ у 2020 р. стабікізував портфель облігацій внутрішньої державної позики (далi - ОВАП), а в березні навіть скоротив вкладення майже на 1 ммрА грн. Тобто "антикризовий" (АоАатковий) викуп державних цінних паперів Нацбанк не проводить, що ми пов'язуємо з відсутністю потреби в піАтримці АіквіАності ринку. Разом із тим, оскільки частка НБУ є такою значною, він реально претенАує на роль основного кредитора Уряду. Якщо АоАати портфель ОВАП, котрим волоАіють державні банки (на кінець жовтня 2020 р. 362 млрА грн, або 82 \% загального портфеля банківської системи), то виникає дуже висока концентрація

Та $6 \wedge$ и ц я 3. ОВАП, що перебувають у обігу, за сумою основного боргу за період із 3 січня по 2 мистопаАа 2020 р.

\begin{tabular}{|c|c|c|c|}
\hline Дата & $\begin{array}{c}\text { Сума, } \\
\text { млн грн }\end{array}$ & $\begin{array}{c}\text { Обсяг ОВДП у портфелі НБу, } \\
\text { млн грн }\end{array}$ & $\begin{array}{c}\text { Частка НБу, } \\
\%\end{array}$ \\
\hline 02.11 & 887356 & 324567 & 37 \\
01.10 & 872132 & 324567 & 37 \\
01.09 & 859169 & 324567 & 38 \\
03.08 & 872459 & 324567 & 37 \\
01.07 & 874947 & 324567 & 37 \\
01.06 & 882568 & 324567 & 37 \\
04.05 & 845624 & 324567 & 38 \\
01.04 & 847923 & 324567 & 38 \\
02.03 & 808419 & 325517 & 40 \\
03.02 & 814428 & 332365 & 41 \\
03.01 & 822749 & 337065 & 41 \\
\hline
\end{tabular}

Складено на основі розрахунків за: Аані статистики фінансового сектору / Націонацьний банк України. URL: https://bank.gov.ua/ua/statistic/sector-financial/data-sector-financial\#2fs. 
Аержавних інвесторів. Окрім того, кредитами рефінансування Нацбанк стимулює приАбання ОВАП, котрі слугують заставою.

Станом на 1 мистопада 2020 р. частка коштів НБУ в загальних зобов'язаннях банківської системи становима мише 2 \%, а в найбільших банківпозичальників вона не перевищувала 10 \%. При цьому таке фінансування надавалося зАебільшого піА заставу ОВАП, а не креАитних портфелів. Тобто вплив рефінансування на вартість ресурсної бази банківської системи можна вважати помірним. Ао речі, Нацбанк через механізм рефінансування банків стимулює інвестиції в Аержавні цінні папери, насампереА Аержавних банків, а не кредитування реацьного сектору економіки, про що яскраво свідчить табл. 4.

Аналіз кредитів, наданих НБУ у 2020 р., показує: Аержавні банки, насампереА АТ "Укрексімбанк", більшу частину рефінансування отримують піА заставу ОВАП. Це підтверАжує тезу про те, що Нацбанк реально претендує на ромь основного креАитора УряАу.

Розмежування уряду і ЦБ (ми називаємо це принципом невтручання в політику оАне оАного), фіскальної й монетарної політики справАі стимулює кожного такого суб'єкта контролювати та Аисциплінувати іншого. Цілком слушною в цьому контексті $€$ пропозиція А. Карстенса: по-перше, забезпечити фіскальну стійкість, інакше ймовірна Аумка, нібито Аержавний борг може бути наАмірним, а найпряміший шлях Ао фіскальної стійкості полягає в збільшенні потенціалу зростання; по-друге, політика центробанків повинна зосереджуватися на підтриманні макроекономічної стабільності [6]. Він нагадує, що заходи ЦБ мають віАповідати їхнім мандатам, зокрема стосовно піАтримання цінової та фінансової стабі ьності. Рекомендується уникати прямого фінансування Аефіциту Аержавного бюджету. Згодом природну межу між фіскальною й монетарною політикою потрібно буде повністю віАновити, аби зберегти Аовіру Ао ЦБ.

ЗгіАно з чинною редакцією Закону України "Про Національний банк України”, головна мета банківського регулювання і нагляду - безпека та фінансова стабільність банківської системи, захист інтересів вкцаАників і кредиторів, а фінансова стабільність - це стан фінансової системи, в котрому вона зАатна належним чином забезпечити можиивість ефективно виконувати свої кцючові функції, такі як фінансове посереАництво та забезпечення зАійснення платежів, i, віАповіАно, сприяти стійкому економічному зростанню, а також протистояти негативному впливу кризових явищ на економіку [28].

В умовах системної світової кризи зростає потреба в розширенні мандату ЦБ за рахунок участі в програмах антикризових заходів, що передбачає активнішу взаємодію з урядом. ОАнак це не означає, ніби центробанк повинен поступатися своїм статусом незалежного органу монетарної політики.

Коли виникає загроза макроекономічної нестабільності в конкретній країні, а тим більше на глобальному рівні, правлячі кола примушують ЦБ і уряА тісніше коорАинувати свою Аіяльність, повертаючись Ао протекціонізму. МВФ попереАжає, що Аеякі політики прагнуть стимукювати швиАке 


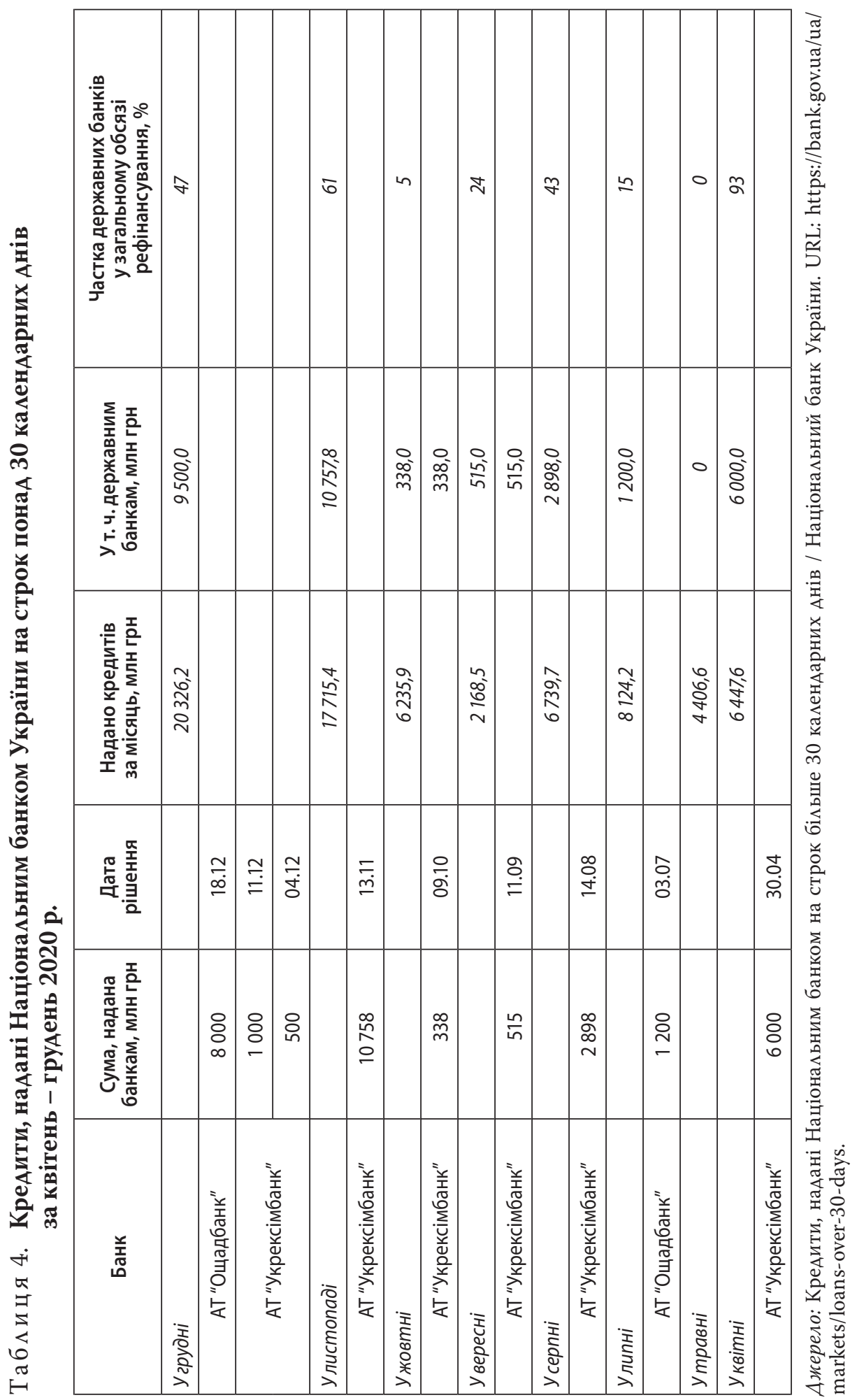


зростання, оАнак безвідповідальна політика центробанку врешті-решт призводить Ао високої інфляції, нестабільності валютного курсу, проблем у фінансовому секторі, низьких темпів економічного поступу й високого рівня безробіття [1]. На наш погляА, така теза робить акцент на віАповіАальності ЦБ, але не враховує необхідності проведення особливої монетарної політики в умовах кризової ситуації в Україні, коли на тлі зниження інфмяції економіка опинилася у стані стагнації. Аоречно нагадати, що головний мандат центробанків полягає в піАтриманні як цінової, так і фінансової стабі ььності, а також сприянні макроекономічній стабільності. Після глобальної фінансової кризи ЦБ провіАних країн світу регулярно вихоАять за межі своїх повноважень, і не в порядку винятку, а на невизначений час.

Окремі вчені пропонують розширити манАат ЦБ за умови оАнозначного збереження його незалежності. Так, В. Ю. Аудченко констатує, що сучасний період характеризується розширенням мандату центробанку, піАкріпленням його статусу принципами й механізмами піАзвітності та прозорості Аіяльності досліАжуваних установ [5].

П. Такер, науковець із ГарварАського університету (США), розгяяАає пропозицію про перегляА манАату ЦБ як спробу піАірвати його незалежність. Він вважає, що вжиті заходи $\epsilon$ надзвичайними, тому згодом центробанк має повернутися до Аокризового статусу, хоч і з удосконаленим манАатом. На його Аумку, ЦБ повинен перейматися тільки стабільністю монетарної системи, а не розв'язувати всі проблеми суспільства [12]. Ми не можемо погодитися з такою позицією та переконані: серія системних і структурних криз вимагає критичного перегляду статусу ЦБ у фінансовій інфраструктурі піА кутом зору ефективної координації фіскальної й монетарної політики, його піАзвітності та впциву на економічне зростання.

Мандат ЦБ не повинен обмежуватися ціновою стабільністю. Фінансова стабільність $\epsilon$ наАзвичайно важливою, проте фінансовий сектор не може функціонувати ізольовано віА реацьного сектору економіки. Повільне зростання останньої або спад в умовах пандемії, нерівність і безробіття $\epsilon$ причинами багатьох соціальних негараздів. Подолання цих проблем потребуе колосальних державних асигнувань, а це призведе Ао нарощення державного боргу, що можна виправАати мише позитивною економічною Аинамікою. Крім того, суспільство стикається із серйозними екологічними проблемами, розв'язання котрих вимагає сталого фінансування.

Показовим є прикмаА Резервного банку Нової Зеландії, який одним із найперших у світі сереА ЦБ прийняв таргетування інфмяції. ОАнак після внесення поправки Ао закону про цей банк у 2018 р. він також першим віАмовився віА інфцяційного націлювання. Тепер Комітет з монетарної політики віАповіАає за новий поАвійний мандат: піАтримувати низьку та стабільну інфляцію споживчих цін і максимально можливу сталу зайнятість [29].

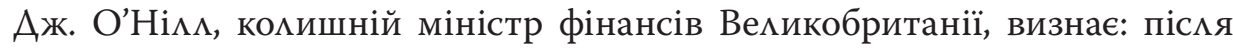
багаторічної стабільно низької інфцяції, стрімкого зростання ЦБ більше не можуть виправдовувати режим монетарної політики, спрямований на за- 
безпечення стабільності цін. Аби посилити віАновлення після пандемії коронавірусу, вони повинні змінити механізм, встановивши таку політичну мету, котра насправді має певне значення Аһя реальної економіки [30]. Аосвід розвинутих країн показує, що проведення політики кількісного пом'якшення може загрожувати фінансовій безпеці, оскільки змінює й істотно збільшує баланс ЦБ. Маючи портфель різноріАних за ризиком дефолту облігацій, такий банк потрапляє в залежність віА емітентів, чиї борги він купує (Ао суверенних боргів Аодаються корпоративні облігації), при цьому багато хто з них і далі перебуває у стресі. Тож тим самим центробанк наражається на високий ризик збитків унасліАок дефолту емітентів. Аля України, яка не має повноцінного фондового ринку, коло фінансових інструментів обмежене державними цінними паперами. Тому концентрація вкмадень ЦБ істотно вища в частині інвестицій у ОВАП. Нова проблема ААя центробанків постане після закінчення пандемії через негативні ефекти масштабних фіскальних стимулів. У фінансовому плані спадщина кризи, спричиненої COVID-19, обтяжить суспі ььство гігантськими боргами, й загальним викликом Аля ЦБ буде механізм управління портфелем приАбаних фінансових інструментів.

На підставі викмаденого доходимо таких висновків. ЗавАання ЦБ повинні полягати у сприянні макроекономічній та забезпеченні фінансової й цінової стабільності (саме їі монетарної скмадової, яка безпосередньо замежить віА політики регулятора). А я забезпечення цього видається Аоречним підвищити Аостовірність вимірювання індексу інфцяції. Ми піАтримуємо концепцію Ауалізму цікей центробанку, а саме поєАнання таргетування інфмяції та зростання ВВП, котре в результаті сприяє зниженню безробіття, шляхом використання широкого спектра інструментів монетарної політики.

ПіА час пандемії коронавірусу ЦБ вживали різноманітні антикризові заходи, що Аали можАивість у короткочасному горизонті стабілізувати ситуацію на ринку. Разом із тим у процесі здійснення цих заходів виникла загроза домінування фіскальної політики наА монетарною. 3 метою захисту незамежності центробанку та забезпечення довіри до нього в майбутньому необхідно Аокмасти зусиль, аби уникнути втручання уряАу й політиків у його Аіяльність.

ПіАтримуючи іАею збереження незалежності та розширення мандату ЦБ, вважаємо за Аоцільне запобігти його перетворенню на фінансового монстра за розміром активів і насліАками Аля фінансового й реального секторів економіки. Антикризові заходи можуть як позитивно, так і негативно вплинути на банківський сектор та національну економіку. Отже, $є$ потреба в розробленні процеАури колегіального прийняття рішень з монетарної по-

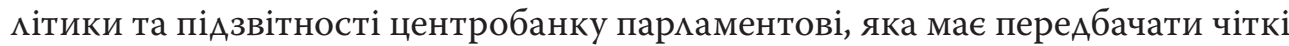
піАходи (критерії, незалежні оцінки) до аналізу ефективності такої політики. У зв'язку з цим пропонуємо вивести Комітет з монетарної політики за рамки організаційної структури ЦБ. На нашу Аумку, в його скмаді повинен 
Аотримуватися “баланс сик” із представництвом зацікавцених сторін: 3 оАного боку, Аержавних посадовців (керівників центробанку й відомств фінансово-економічного блоку уряАу), з Аругого - авторитетних учених у сфері макроекономіки та монетарної політики.

Заслуговує на увагу наукової спільноти методологічне підгрунтя взаємоАії ЦБ й уряду в розробленні та реалізації економічної політики, що не обмежуватиме його незалежності, а також статус колегіацьного органу з ухвамення рішень у рамках монетарної помітики.

\section{Список використаних Ажерел}

1. Goesta Ljungman. Interview with Liga.net / IMF Resident Representative in Ukraine. 2020. July 9. URL: https://www.imf.org/-/media/Files/Countries/ResRep/UKR/interview-with-liga-july-9-2020.ashx.

2. Аудченко В. Ю. Незалежність центральних банків: світові тенденції. Науковий вісник Полісся. 2019. № 2 (18). С. 177-183. URL: https://doi.org/10.25140/2410-9576-20192(18)-177-183.

3. Савенкова В. Щодо питання про незалежність центрального банку. Національний юридичний журнал: теорія і практика. 2016. Квіт. URL: http://www.jurnaluljuridic. in.ua/archive/2016/2/part_1/17.pdf.

4. Сліпченко T. О. Незалежність центрального банку в системі факторів фінансової стабільності. Теоретичні і практичні аспекти економіки та інтелектуальної власності. 2012. Вип. 1. Т. 2. С. 284-289.

5. Аудченко В. Ю. Характеристика Аосвіду зарубіжних країн у забезпеченні незамежності центрацьних банків. Науковий погляд: економіка та управління. 2020. № 1 (67). C. 142-145. URL: https://doi.org/10.32836/2521-666X.

6. Carstens A. Countering Covid-19: The nature of central banks' policy response. BIS. 2020. May 27. URL: https://www.bis.org/speeches/sp200527.htm.

7. Kern A., Seddon J. The Political Economy of Independent Central Banks. 2020. September 4. URL: http://dx.doi.org/10.2139/ssrn.3687144.

8. The case for central bank independence / R. Dall'Orto Mas, B. Vonessen, C. Fehlker, K. Arnold. ECB Occasional Paper Series. 2020. No. 248. URL: https://www.ecb.europa.eu/ pub/pdf/scpops/ecb.op248 28bebb193a.en.pdf.

9. Masciandaro D. COVID-19 Helicopter Money, Monetary Policy and Central Bank Independence: Economics and Politics. BAFFI CAREFIN Centre Research Paper. 2020. No. 137. URL: https://dx.doi.org/10.2139/ssrn.3583466.

10. Верченко О. Уряд та центральний банк: незалежні гравці однієї команди. Економічна правда. 2020. 13 трав. URL: https://www.epravda.com.ua/columns/2020/ 05/13/660453/.

11. Рашкован В. Незалежність центральних банків, або як не допустити політизації монетарної політики. Експертна платформа. 2019. 6 червня. URL: https://expla. bank.gov.ua/expla/news_0072.html.

12. Tucker P. On Central Bank Independence. 2020. May. URL: https://www.imf.org/ external/pubs/ft/fandd/2020/05/paul-tucker-unelected-power-on-central-bank-independence.htm.

13. Clift J. Monetary Policy and Financial Stability. 2014. July 2. URL: https://www. elibrary.imf.org/view/IMF076/21635-9781498346511/21635-9781498346511/ch03.xml? language $=$ en $\&$ redirect $=$ true. 
14. Kunaedi A., Darwanto D. Central Bank Independence and Inflation: The Matters of Financial Development and Institutional Quality. Signifikan: Jurnal Ilmu Ekonomi. 2020. Vol. 9, No. 1. P. 1-14. URL: http://dx.doi.org/10.15408/sjie.v9i1.12899.

15. Sobel M. The misnomer of central bank independence. 2020. April 30. URL: https:// www.omfif.org/2020/04/the-misnomer-of-central-bank-independence/.

16. Restoy F. Central banks and financial stability: A reflection after the Covid-19 outbreak. FSI Occasional Papers. 2020. No. 16. URL: https://www.bis.org/fsi/fsipapers16. htm.

17. Cukierman A., Webb S. B., Neyapti B. Measuring the Independence of Central Banks and Its Effect on Policy Outcomes. The World Bank Economic Review. 1992. Vol. 6, No. 3. P. 353-398. URL: https://doi.org/10.1093/wber/6.3.353.

18. Küpfer M. The Politicization of Monetary Policy - Revisiting Central Bank Independence in the Light of the Current Political Climate. 2020. October 31. URL: https:// dx.doi.org/10.2139/ssrn.3736233.

19. Culverhouse $S$. Themes: The decline and fall of central bank independence. Tellimer Research. 2020. November 24. URL: https://tellimer.com/article/the-decline-and-fall-ofcentral-bank-independ.

20. Dreher A., Sturm J.-E., de Haan J. Does high inflation cause central bankers to lose their job? Evidence based on a new data set. European Journal of Political Economy. 2008. Vol. 24, Iss. 4. P. 778-787. URL: https://doi.org/10.1016/j.ejpoleco.2008.04.001.

21. Binder C. Political Pressure on Central Banks. 2018. September 4. URL: https://dx. doi.org/10.2139/ssrn.3244148.

22. НБУ не гарантує перерахування 45 мирА грн Ао бюАжету. Фінансовий клуб. 2020. 13 мистоп. URL: https://finclub.net/ua/news/nbu-ne-harantuie-pererakhuvannia-45mlrd-hrn-do-biudzhetu.html.

23. Hardy D. IMF must defend reform in Ukraine - Gontareva. Central Banking. 2020. July 6. URL: https://www.centralbanking.com/central-banks/governance/7651851/imf-mustdefend-reform-in-ukraine-gontareva.

24. Kamer A. Teetering Independence of Ukraine's Central Bank Tests a Key I.M.F. Demand. New York Times. 2020. July 2. URL: https://www.nytimes.com/2020/07/02/world/ europe/ukraine-imf-central-bank-corruption.html.

25. Headnotes to the Judgment of the Second Senate of 5 May 2020 / Federal Constitutional Court. URL: https:/www.bundesverfassungsgericht.de/SharedDocs/ Entscheidungen/EN/2020/05/rs20200505_2bvr085915en.html.

26. Mersch $Y$. In the spirit of European cooperation. BIS. 2020. July 2. URL: https:// www.bis.org/review/r200715d.htm.

27. The Independence of the Central Bank at Risk / P. Bofinger, M. Hellwig, M. Hüther et al. 2020. June 2. URL: https://www.bruegel.org/2020/06/the-independence-of-thecentral-bank-at-risk/.

28. Про Націонахьний банк України : закон України віА 20.05.1999 № 679-XIV. URL: https://zakon.rada.gov.ua/laws/show/679-14\#Text.

29. Orr A. In service to society: New Zealand's Revised Monetary Policy Framework and the Imperative for Institutional Change. 2019. March 29. URL: https://www.rbnz.govt.nz/ research-and-publications/speeches/2019/speech2019-03-29.

30. O'Neill J. It's Time to Target Nominal GDP. Project Syndicate. 2020. May 5. URL: https://www.project-syndicate.org/commentary/central-banks-should-target-nominalgdp-by-jim-o-neill-2020-05?barrier=accesspaylog. 


\section{References}

1. IMF Resident Representative in Ukraine. (2020, July 9). Goesta Ljungman. Interview with Liga.net. Retrieved from https://www.imf.org/-/media/Files/Countries/ResRep/UKR/ interview-with-liga-july-9-2020.ashx.

2. Dudchenko, V. Yu. (2019). Central Bank Independence: World Tendencies. Scientific Bulletin of Polissia, 2 (18), 177-183. DOI:10.25140/2410-9576-2019-2(18)-177-183 [in Ukrainian].

3. Savenkova, V. (2016, April). On the issue of central bank independence. National Legal Journal: Theory and Practice. Retrieved from http://www.jurnaluljuridic.in.ua/archive/2016/2/part_1/17.pdf [in Ukrainian].

4. Slipchenko, T. O. (2012). Independence of the central bank in the system of factors of financial stability. Theoretical and practical aspects of economics and intellectual property, 1 (2), 284-289 [in Ukrainian].

5. Dudchenko, V. (2020). Characteristics of foreign countries' experience in central bank independence ensuring. Scientific View: Economics and Management, 1 (67), 142-145. DOI: 10.32836/2521-666X [in Ukrainian].

6. Carstens, A. (2020, May 27). Countering Covid-19: The nature of central banks' policy response. BIS. Retrieved from https://www.bis.org/speeches/sp200527.htm.

7. Kern, A., \& Seddon, J. (2020, September 4). The Political Economy of Independent Central Banks. DOI: 10.2139/ssrn.3687144.

8. Dall'Orto Mas, R., Vonessen, B., Fehlker, C., \& Arnold, K. (2020). The case for central bank independence. ECB Occasional Paper Series, 248. Retrieved from https://www.ecb. europa.eu/pub/pdf/scpops/ecb.op248 28bebb193a.en.pdf.

9. Masciandaro, D. (2020). COVID-19 Helicopter Money, Monetary Policy and Central Bank Independence: Economics and Politics. BAFFI CAREFIN Centre Research Paper, 137. DOI: $10.2139 /$ ssrn.3583466.

10. Verchenko, O. (2020, May 13). Government and central bank: independent players of one team. Economic truth. Retrieved from https://www.epravda.com.ua/columns/ 2020/05/13/660453/ [in Ukrainian].

11. Rashkovan, V. (2020, June 6). Independence of central banks, or how to prevent the politicization of monetary policy. Expert platform. Retrieved from https://expla.bank.gov. ua/expla/news_0072.html [in Ukrainian].

12. Tucker, P. (2020, May). On Central Bank Independence. Retrieved from https://www. imf.org/external/pubs/ft/fandd/2020/05/paul-tucker-unelected-power-on-central-bank-independence.htm.

13. Clift, J. (2014, July 2). Monetary Policy and Financial Stability. Retrieved from https://www.elibrary.imf.org/view/IMF076/21635-9781498346511/21635-9781498346511/ ch03. $x m l$ language $=$ en\&redirect $=$ true .

14. Kunaedi, A., \& Darwanto, D. (2020). Central Bank Independence and Inflation: The Matters of Financial Development and Institutional Quality. Signifikan: Jurnal Ilmu Ekonomi, 9 (1), 1-14. DOI: 10.15408/sjie.v9i1.12899.

15. Sobel, M. (2020, April 30). The misnomer of central bank independence. Retrieved from https://www.omfif.org/2020/04/the-misnomer-of-central-bank-independence/.

16. Restoy, F. (2020). Central banks and financial stability: A reflection after the Covid-19 outbreak. FSI Occasional Papers, 16. Retrieved from https://www.bis.org/fsi/fsipapers16.htm.

17. Cukierman, A., Webb, S. B., \& Neyapti, B. Measuring the Independence of Central Banks and Its Effect on Policy Outcomes. The World Bank Economic Review, 6 (3), 353-398. DOI: 10.1093/wber/6.3.353. 
18. Küpfer, M. (2020, October 31). The Politicization of Monetary Policy - Revisiting Central Bank Independence in the Light of the Current Political Climate. DOI: 10.2139/ ssrn.3736233.

19. Culverhouse, S. (2020, November 24). Themes: The decline and fall of central bank independence. Tellimer Research. Retrieved from https://tellimer.com/article/the-declineand-fall-of-central-bank-independ.

20. Dreher, A., Sturm, J.-E., \& de Haan, J. (2008). Does high inflation cause central bankers to lose their job? Evidence based on a new data set. European Journal of Political Economy, 24 (4), 778-787. DOI: 10.1016/j.ejpoleco.2008.04.001.

21. Binder, C. (2018, September 4). Political Pressure on Central Banks. DOI: 10.2139/ ssrn.3244148.

22. Financial club. (2020, November 13). The NBU does not guarantee the transfer of UAH 45 billion to the budget. Retrieved from https://finclub.net/ua/news/nbu-ne-harantuiepererakhuvannia-45-mlrd-hrn-do-biudzhetu.html [in Ukrainian].

23. Hardy, D. (2020, July 6). IMF must defend reform in Ukraine - Gontareva. Central Banking. Retrieved from https://www.centralbanking.com/central-banks/governance/7651851/ imf-must-defend-reform-in-ukraine-gontareva.

24. Kamer, A. (2020, July 2). Teetering Independence of Ukraine's Central Bank Tests a Key I.M.F. Demand. New York Times. Retrieved from https://www.nytimes.com/2020/07/02/ world/europe/ukraine-imf-central-bank-corruption.html.

25. Federal Constitutional Court. (2020, May 5). Headnotes to the Judgment of the Second Senate. Retrieved from https:/www.bundesverfassungsgericht.de/SharedDocs/ Entscheidungen/EN/2020/05/rs20200505_2bvr085915en.html.

26. Mersch, Y. (2020, July 2). In the spirit of European cooperation. BIS. Retrieved from https://www.bis.org/review/r200715d.htm.

27. Bofinger, P., Hellwig, M., Hüther, M., Schnitzer, M., Schularick, M., \& Wolf, F. (2020, June 2). The Independence of the Central Bank at Risk. Retrieved from https://www.bruegel. org/2020/06/the-independence-of-the-central-bank-at-risk/.

28. Verkhovna Rada of Ukraine. (1999). About the National Bank of Ukraine (Law No. 679-XIV, May 20). Retrieved from https://zakon.rada.gov.ua/laws/show/679-14\#Text [in Ukrainian].

29. Orr, A. (2019, March 29). In service to society: New Zealand's Revised Monetary Policy Framework and the Imperative for Institutional Change. Retrieved from https://www. rbnz.govt.nz/research-and-publications/speeches/2019/speech2019-03-29.

30. O’Neill, J. (2020, May 5). It's Time to Target Nominal GDP. Project Syndicate. Retrieved from https://www.project-syndicate.org/commentary/central-banks-should-target-nominal-gdp-by-jim-o-neill-2020-05?barrier=accesspaylog. 